ARTICLE

https://doi.org/10.1057/s41599-018-0205-6

\title{
Responding to volcanic eruptions in Iceland: from the small to the catastrophic
}

\author{
Deanne K. Bird ${ }^{1} \&$ Guðrún Gísladóttir ${ }^{1,2}$
}

\begin{abstract}
There is no doubt that as the world's population continues to grow and expand in hazardous environments, so too does our vulnerability to disaster. Researching disaster risk is therefore an ongoing challenge requiring a continual process of generating understanding of the changing environmental and societal characteristics that influence disaster vulnerability. Iceland, as the land of fire and ice, is of no exception. With a changing population, exponential growth in tourism and a volcanic eruption on average every 3-4 years, disaster risk research is of critical importance. Based on questionnaire survey results, interviews with key stakeholders and data derived from Statistics Iceland, this paper considers how residents might respond to a future eruption by examining their experience of the 2010 Eyjafjallajökull eruptions against the changing demographic, economic and political landscape. While authorities were pleased with public response to evacuation orders in 2010, some residents did not evacuate. The reasons for not evacuating were due to caring for others or thinking the warnings were not applicable. Yet, most residents showed respect for authority and acknowledged the necessity of the evacuations. The relatively small, homogenous population of Iceland coupled with its peoples' desire to cooperate contributed to this success. Within these communities, people are bound together by common beliefs, values and activities. However, the changing social landscape will test this phenomenon. In particular, the region's economic base is evolving from traditional farming practices to one that is increasingly reliant on tourism. Demographic changes most notably include greater international migration to the South, as well as from the capital region. As the communities diversify, so too will people's beliefs, values and activities. This paper explores the challenges this diversity brings with respect to generating a proactive public response to future evacuation orders. Furthermore, it highlights the importance of capturing narratives of actions and activities to enhance our understanding of the process of decision-making and the situational factors that add to its complexity.
\end{abstract}

\footnotetext{
${ }^{1}$ Faculty of Life and Environmental Sciences, University of Iceland, Reykjavík, Iceland. ${ }^{2}$ Nordvulk, Institute of Earth Sciences, University of Iceland, Reykjavík, Iceland. Correspondence and requests for materials should be addressed to D.K.B. (email: dkb@hi.is)
} 


\section{Introduction}

$\mathrm{V}$ ulnerability to natural hazard risk is complex. At-risk populations are not only vulnerable due to a range of economic, demographic and political elements often beyond their control (Wisner et al., 2004), but also in relation to the various factors that affect their decision-making. For example, people's decision to comply with evacuation orders may be influenced by their ability to perform the required action, the availability of information about the threat, trust in the source of that information and feelings of responsibility to undertake the prescribed action (Bird et al., 2009b, Bird et al., 2011, Drabek, 1999, Haynes et al., 2008, Mileti et al., 2004, Strahan et al., 2018).

Disaster researchers have, however, applied a range of theoretical perspectives to enhance our understanding of the process of decision-making in response to imminent threats. Combining various elements from these (e.g., Emergent Norm Theory, Protection Motivation Theory, Behavioural Decision Theory, Classical Persuasion Model, Attitude-Behaviour Theory), Lindell and Perry (2004) produced an integrated model entitled the Protective Action Decision Model (PADM - see Lindell and Perry (2004) for a description of each of these theories and models and how they relate to the PADM). The PADM shows that decision-making is initiated by environmental cues (e.g., the sight or sound of an eruption), social cues (e.g., neighbours evacuating) and/or warnings (e.g., official advice to evacuate). These trigger a series of pre-decisional processes that stimulate the receiver to consider their perception of the threat, alternative options for protective action and their perceptions of the relevant stakeholders involved (Lindell and Perry, 2012).

While the PADM identifies the way people 'typically' make decisions, Lindell and Perry, (2012) recognise that various situational facilitators and impediments influence their response. These include individual-level indicators and event-orientated variables (Dash and Gladwin, 2007) such as their perception of the ensuing event, the perceived safety of their home relative to the threat, timing of evacuation (e.g., are the roads already congested with traffic, are all household members accounted for) and past experiences (Drabek, 1986, Gladwin et al., 2001, Mileti and Peek, 2000, Paton et al., 2001, Sorensen and Sorensen, 2007, Tierney et al., 2001).

This paper draws on these learnings to consider future response to an evacuation order with respect to a region's recent experience of responding to evacuation orders. The experience that is the focus of this paper is the response to the 2010 Eyjafjallajökull eruptions. The first of these events began on $20 \mathrm{March}$ 2010 and consisted of a 24-day long flank eruption at Fimmvörðuháls (Fig. 1) producing spectacular fire-fountain activity and lava flows. The flank eruption was followed 1-2 days later (14 April) by a far more explosive 39-day long summit eruption resulting in medium-sized jökulhlaups (glacial outburst floods) to the north, small jökulhlaups and lahars to the south and considerable ash fall to the east and east-southeast of the volcano (Porkelsson, 2012). Together, these eruptions caused considerable damage and ongoing challenges to local residents (Bird and Gísladóttir, 2012).

These eruptions, however, did not occur without warning. The regional Chief of Police and the Department of Civil Protection and Emergency Management (DCPEM) held meetings with scientists, local police and rescue teams in response to increased seismicity in and around Eyjafjallajökull in early 2010. Multiple community meetings were also held with residents living in the expected hazard zone. Evacuation plans, based on a 2005 hazard assessment (see Guðmundsson and Gylfason, 2005), were finalised during this period (Bird et al., 2011). An immediate evacuation was considered critical, given the assessment showed that inhabited areas may be flooded by a jökulhlaup within an hour of an eruption commencing in Eyjafjallajökull (Sigurðsson et al., 2011). As a consequence, several evacuation orders were issued during the 2010 events via the automated phone alert system, supervised by the local Chief of Police. In addition, the sweeper system was deployed. Consisting of local residents as volunteers, some of whom form part of the local rescue team, their role is to 'sweep' their neighbourhood by going from house to house to ensure everyone has received the warnings and have, or are in the process of evacuating to their designated centre (Bird et al., 2009b).

A few months following the eruptions, we conducted a survey to investigate how impacted residents responded to and coped with the events. This paper considers how residents might respond to future evacuation orders by examining the results of that survey against the changing demographic, economic and political structure of South Iceland. Considering future response in this region is important given Katla is renowned as one of Iceland's most dangerous volcanoes due to its potential to produce catastrophic jökulhlaup ( $>100,000 \mathrm{~m}^{3} \mathrm{~s}^{-1}$ ) within $1^{1 / 2}$ to $2 \mathrm{~h}$ (Guðmundsson and Gylfason, 2005, Guðmundsson et al., 2007) warranting the need for an immediate response to evacuation orders. Furthermore, South Iceland's Hekla, Katla, Grímsvötn and Bárðarbunga volcanoes (Fig. 2), and their associated fissure systems, have the highest eruption frequency and greatest volcanic productivity in Iceland (Thordarson and Larsen, 2007). In addition to these systems, recent unrest in Öræfajökull has called for the development of further emergency response plans in South Iceland (Almannavarnadeild Ríkislögreglustjórinn, 2017, Höskuldsson, 2015).

\section{Methods}

2010 Eyjafjallajökull survey. The survey implemented in 2010 incorporated 15 semi-structured interviews with officials, rescue team members and residents alongside a questionnaire disseminated to households living within the hazard zones of the Eyjafjallajökull and Katla volcanoes (see Fig. 1 and Bird et al., (2011)). The questionnaire developed for this survey was modelled on those implemented in a longitudinal study on knowledge and perceptions related to a possible Katla eruption (see Bird et al., 2009a, Bird et al., 2009b, Bird et al., 2011, Jóhannesdóttir and Gísladóttir, 2010). Additional aspects, however, were included to examine experiences related to the Eyjafjallajökull eruptions. Some questions regarding Katla were retained because the Katla hazard zones cover the same communities impacted by the Eyjafjallajökull eruptions. Also, there was much media focus on a Katla eruption being generated because of the Eyjafjallajökull eruptions. Furthermore, earlier response plans were centred on a Katla eruption rather than a response to an Eyjafjallajökull eruption.

Out of 61 households approached to take part in the survey, 58 completed the questionnaire (one respondent per household) giving a response rate of $95 \%$. This included 19 households from Vestur-Eyjafjöll, 26 from Austur-Eyjafjöll, seven from Sólheimar and six from Álftaver (see Fig. 1). These communities were targeted due to their exposure to volcanic hazards during the 2010 eruptions/their locations in relation to Katla's jökulhlaup hazard zones (for details on the hazard zones, see Bird et al., 2011). More specifically:

- Households in Vestur-Eyjafjöll were required to evacuate due to jökulhlaup hazard during the flank and summit eruptions in Eyjafjallajökull. During these events this area was impacted by jökulhlaup, ash fall, lightning, loud sound blasts and rock fall. This area also lies within the western jökulhlaup hazard zone for a Katla eruption.

- Households in Austur-Eyjafjöll were required to evacuate due to jökulhlaup hazard during the flank and summit eruptions in Eyjafjallajökull. During these events they were impacted by 


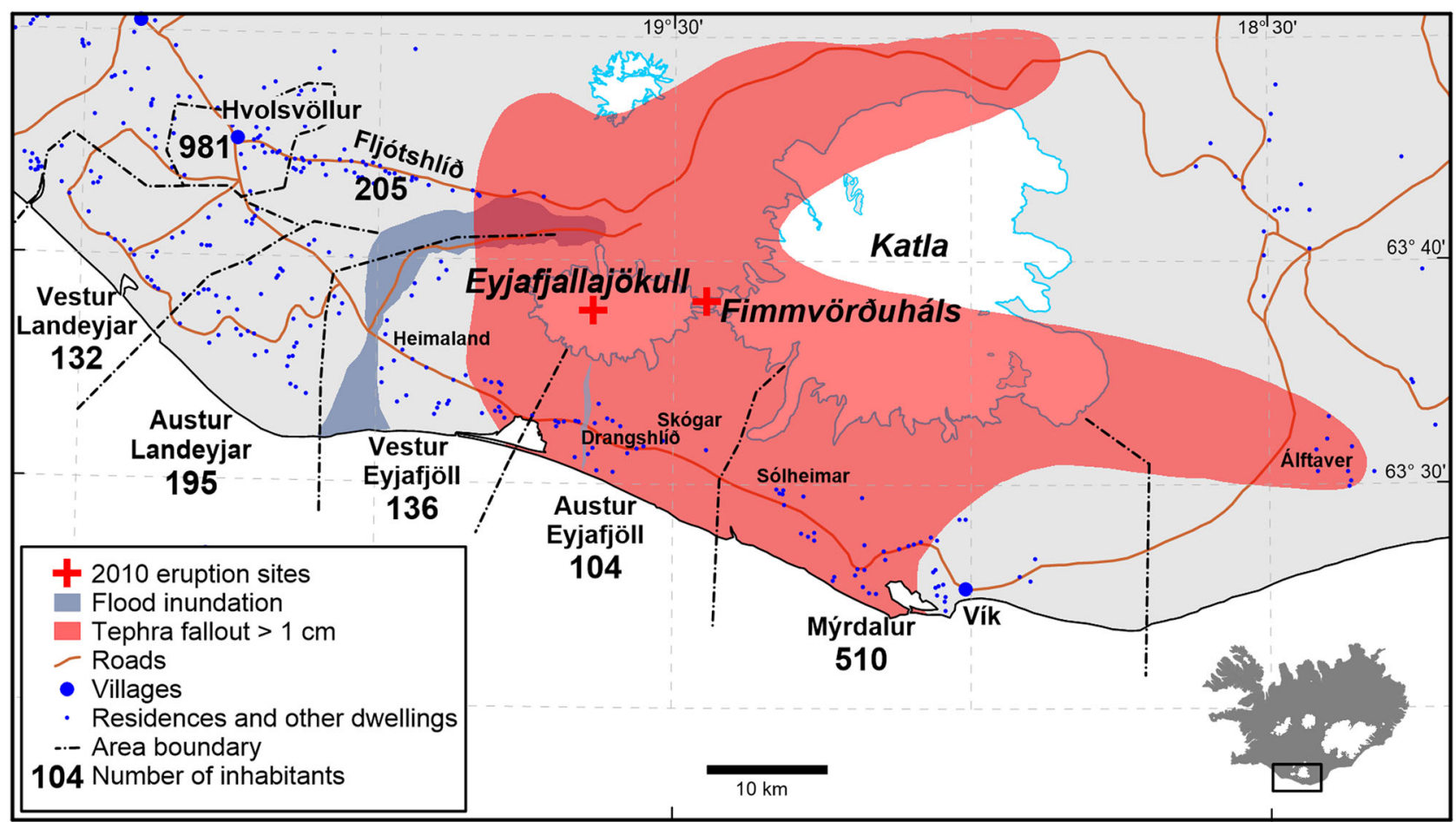

Fig. 1 Communities impacted by jökulhlaup (flood) inundation and ash fall exceeding $1 \mathrm{~cm}$ (from Bird et al., 2018). Tephra fallout and flood inundation data derived from Gudmundsson et al., (2012) and Porkelsson (2012). Population data sourced from Ísólfur Gylfi Pálmason, the head of the Rangárping eystra municipality, and Statistics Iceland (2016). Map produced by Pórdís Högnadóttir

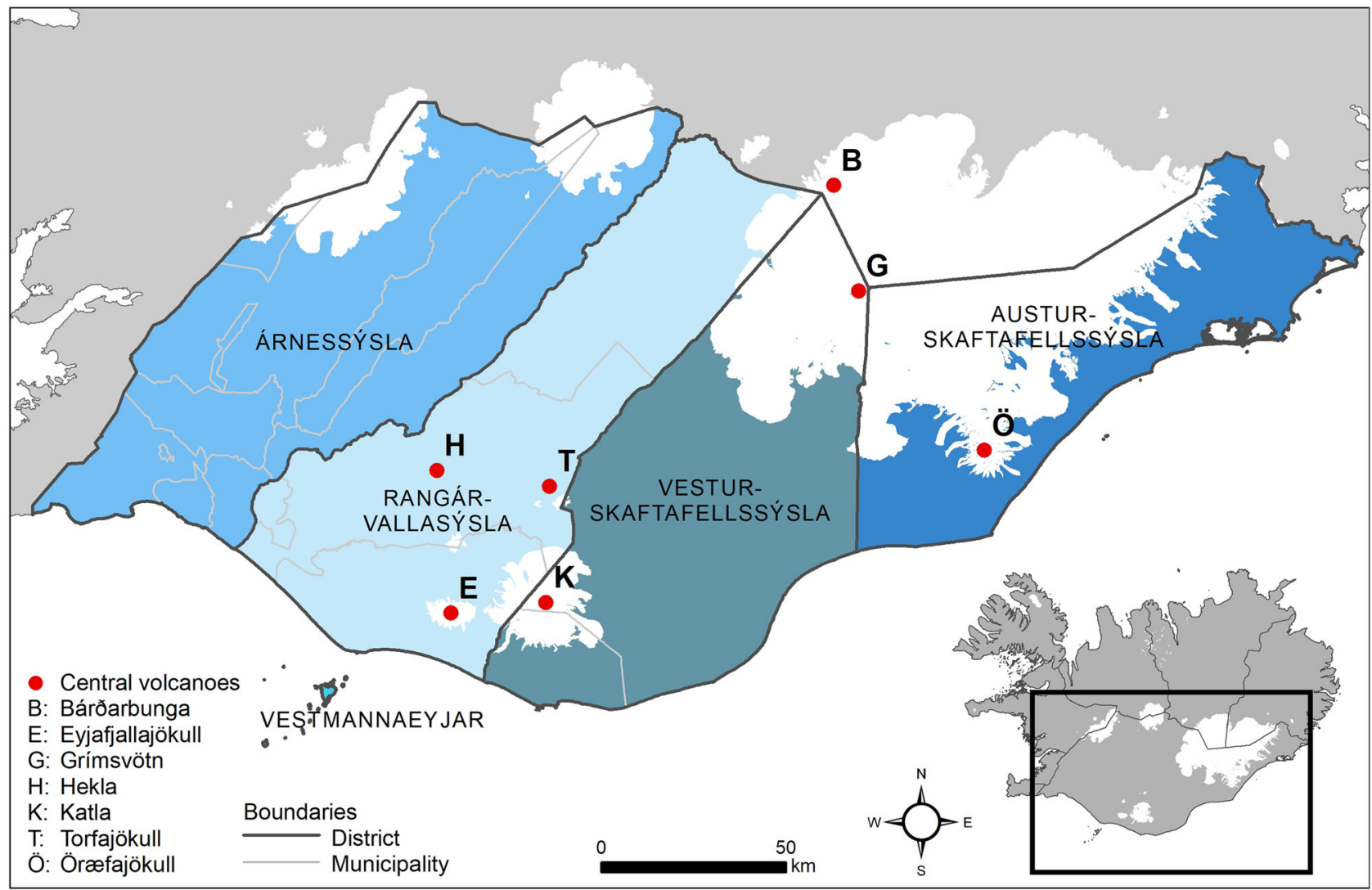

Fig. 2 The volcanoes and districts of Iceland's South region. Map produced by Olga Kolbrún Vilmundardóttir. The different coloured blue areas denote the four districts 
jökulhlaup, ash fall, lightning, loud sound blasts and lahars.

- Sólheimar lies within the southern jökulhlaup hazard zone for a Katla eruption and during the Eyjafjallajökull summit eruption they were impacted by considerable ash fall and loud sound blasts.

- Álftaver lies within the eastern jökulhlaup hazard zone for a Katla eruption and was the first community to be blanketed by ash fall during the Eyjafjallajökull summit eruption.

Please note, due to time pressures the community of Skógar (Austur- Eyjafjöll) was not included in this study. The decision to omit Skógar was based on the fact that it is located further from the eruption site than other communities in Austur- Eyjafjöll and it is not situated in a jökulhlaup hazard zone for an Eyjafjallajökull or Katla eruption.

While the sample size may seem small, it is a reflection of this sparsely populated rural area (as evidenced by the number of inhabitants given in Fig. 1). Due to the small population size, a census style sampling method was undertaken. That is, we endeavoured to capture perspectives from every permanent household within these communities. However, 14 households were unavailable during the interview and questionnaire dissemination period, which was conducted over 10 days in August 2010. Each household was visited at least twice during the day.

Overall, the 58 households represent approximately 141 adults and 38 children. These figures are approximate based on some respondents noting a range in the number of people living at that address in the questionnaire. This range is a reflection of youths and adults being registered to that household while residing in a different location to attend school or university.

The questionnaire and semi-structured interviews were comprehensive, taking $30-45 \mathrm{~min}$ and up to $2 \mathrm{~h}$ and $36 \mathrm{~min}$ to complete, respectively. The questionnaire included 92 open and closed response questions compiled into the following 10 sections, which also formed the basis of the semi-structured interviews.

1. Demographics;

2. Experience prior to and during the flank eruption that began on 20th March in Fimmvörðuháls;

3. Experience prior to and during the summit eruption that began on 14th April under Eyjafjallajökull;

4. Impacts of the eruptions on you, your family and property;

5. Impact on agriculture;

6. Impact on tourism;

7. Use of various media sources for acquiring information about the possibility of a future Katla/Eyjafjallajökull eruption;

8. Perceived level of preparedness for a future Katla eruption;

9. Perceived possibility of a future Katla eruption and its effects;

10. Trust in information from various sources about a future Katla eruption.

The questionnaire was administered as a hardcopy. All data was entered into SurveyMonkey and exported into Microsoft Excel for analysis. As cloud-based software, Survey Monkey ensures greater access across our research team to the questionnaire and its data for use in future projects, reduces the risk of errors during data entry (when compared for example to manually entering coding into Excel) and allows an easy visualisation for crosschecking each entry to ensure accuracy. Its use post-surveying here was a result of unavailability of the software to our research team pre-surveying.

The semi-structured interviews were audio recorded and transcribed by us. Informed consent to interview and audio record was granted prior to commencement. Transcripts were analysed and coded according to the core topics of the 2010 questionnaire. The transcripts underwent a further analysis to capture detail and nuances within the data that relate to the aims of this paper. The items of import to this paper are: demographics; impact of the eruptions; receipt of cues and warnings; public response; perceived levels of coping; and, perceptions of the future. With respect to the latter, we draw similar data (i.e., from Bird et al., 2011) obtained prior to the eruptions to compare against post-event perceptions. Other aspects of the 2010 survey have been published elsewhere (Bird and Gísladóttir, 2012, Bird and Gísladóttir, 2014, Bird et al., 2018).

2016 interviews. Follow-up interviews were conducted in 2016 with the Chief of Police, the Chief Superintendent, the head of Rangárping eystra and two local residents who operated both farming and tourism businesses. While the nature of the 2016 project prevented a more broad survey, as that conducted in 2010, it provided an excellent opportunity to exchange and discuss valuable information with authorities in regards to developments in volcanic emergency response strategies on the back of learnings from the 2010 Eyjafjallajökull eruptions and our survey data. These targeted, face-to-face meetings also provided the opportunity to explore regional economic, demographic and political changes.

Conducted as a more open interview than the rigorous 2010 interviews, the 2016 interviews lasted between 17 and $57 \mathrm{~min}$. As with the semi-structured interviews conducted in 2010, the 2016 open interviews were audio recorded with consent and transcribed by the authors. Transcripts were analysed and coded according to the core topics of the 2010 questionnaire. The transcripts underwent a further analysis to capture detail and nuances that relate to the aims of this paper.

The changing demographics of South Iceland. In order to capture the changing structure and situation in South Iceland in more detail, demographic data held by Statistics Iceland was accessed from www.statice.is and analysed using Microsoft Excel. Of particular import to the study presented here is data pertaining to population, migration and livelihood.

Population data by age and gender is available from 1998. The years of 2000, 2008 and 2016 were selected as equal time periods of available data from the most recent year (i.e., 2016, as accessed in 2017). Population data for this period is available by municipality. Our analysis therefore focused on those municipalities surrounding the Eyjafjallajökull and Katla volcanoes: Mýrdalshreppur (which includes Sólheimar), Skaftárhreppur (which includes Álftaver) and Rangárping eystra (which includes Vestur- and Austur-Eyjafjöll).

In comparison, specific migration details are not available by municipality, i.e., Statistics Iceland only provides aggregated data at a regional level. The municipalities encompassing the South region include Sveitarfélagið Hornafjörður, Vestmannaeyjar, Sveitarfélagið Árborg, Mýrdalshreppur, Skaftárhreppur, Ásahreppur, Rangárbing eystra, Rangárping ytra, Hrunamannahreppur, Hveragerði, Sveitarfélagið Ölfus, Grímsnes- og Grafningshreppur, Skeiða- og Gnúpverjahreppur, Bláskógabyggð and Flóahreppur. Aggregated migration data is presented for South Iceland from 1986-2016 (i.e., the time period available from Statistics Iceland).

Farming has traditionally been the main livelihood in Iceland's South region. The tourism industry, however, is rapidly growing, with the South attracting the highest number of visitors outside the capital region (Bird et al., 2016). Hence, we accessed data on the total number of people employed in main and second jobs held outside the capital region and within the farming (crop and animal production, hunting and related service activities) and tourism sectors. 
Specific livelihood details are not available by municipality, i.e., Statistics Iceland only provides aggregated data from the capital region and outside the capital region. The capital region consists of Reykjavík, Seltjarnarnes, Kópavogur, Hafnarfjörður, Garðarbær, Mosfellsbær, Álftanes and Kjósahreppur. All other municipalities are considered as being outside the capital region. Given the South attracts the highest number of visitors outside the capital region (Bird et al., 2016), it is safe to assume that the changes in livelihood are a reflection of changes in the South. Aggregated livelihood data is therefore presented for outside the capital region from 1991-2016 (i.e., the time period available from Statistics Iceland).

The results section is presented under the three subsections: 2010 Eyjafjallajökull survey, 2016 interviews and the changing demographics of South Iceland. The former two incorporate the qualitative results mixed with verbatim quotes from the 2010 and 2016 interviews and open responses given in the 2010 questionnaire. Each quote is coded as one of the following: V-E for Vestur-Eyjafjöll resident, A-E for Austur-Eyjafjöll resident, S for Sólheimar resident, Á for Álftaver resident, RT for rescue team member and $\mathrm{O}$ for official.

\section{Results}

\section{Eyjafjallajökull survey}

Demographics.

[My family has lived in this region as] far back as I am able to remember $(S)$.

Overall, the 58 households that took part in the survey included approximately 141 adults and 38 children (an approximate is given as some respondents noted that household membership varied with children attending school outside the region). Most respondents were aged $50+$ years and were farmers (Table 1). Many respondents had lived at their address (during surveying) all their lives with almost two-thirds having lived there 30 years or more and most having family in the region for two or more generations, with the longest at seven generations. Only two respondents noted living at that address for less than 5 years.

The majority of respondents declared farming as their occupation. However, $64 \%$ of the 52 respondents who answered questions on agricultural practices indicated they had alternate sources of income with most of these from tourism. An additional 13

\section{Table 1 Respondent demographics}

Age $(n=55)$

\begin{tabular}{lr}
\hline $18<30$ & 10.9 \\
$31<50$ & 29.1 \\
$50+$ & 60.0 \\
Education $(n=58)$ & \\
\hline Some schooling & 6.9 \\
Educated 6 to 16 years & 27.6 \\
High school 16 to 20 years & 8.6 \\
Special education & 24.1 \\
University degree & 15.5 \\
Postgraduate qualification & 5.2 \\
Other & 12.1 \\
Occupation ( $n=57)$ & \\
\hline Farming & 71.9 \\
Tourism & 19.3 \\
Other & 40.4 \\
\hline
\end{tabular}

Some sections do not equal $100 \%$ as multiple responses were permitted

All data given as a percentage respondents indicated they had tourism as their main occupation. Tourism related work mostly (85\%) involved accommodation.

\section{Impact of the eruptions.}

We taped the windows and the doors...by 12:00-14:00 it was completely dark, we could not see anything. It was not only the darkness but also the noise of the eruption for the children and animals. We could not expect our children to stay in the darkness and the hell (A-E).

All respondents were impacted by ash fall, just over a quarter (26\%) were impacted by lahars and $20 \%$ were impacted by jökulhlaup. Overall, respondents ranked impacts on their home as the greatest followed by impacts to them and / or their family emotionally and financially (Table 2).

Of note, $57 \%$ of respondents recorded moderate to extreme impacts to them and/or their family emotionally, with AusturEyjafjöll respondents recording the greatest. Austur-Eyjafjöll respondents also recorded the greatest impacts with respect to their home, while Sólheimar respondents recorded the greatest impacts to them and/or their family's health and financially. These impacts, however, were felt right across the region to Álftaver.

The impacts of the eruption were significant on my farm and at my neighbouring farms. It is very misleading and wrong description that the impacts were confined to Eyjafjöll. The western part of Mýrdalshreppur [municipality] is somewhat forgotten and lost in this all. We still live with ash storm when the wind is blowing (S).

The day after the eruption we felt the ash come over here and it was completely dark. There is an old Icelandic saying: "You couldn't see/distinguish your hands." I now understand this. Never in my whole life have I been in such darkness. (Á).

Despite this, some appreciated the eruption for its sheer beauty and force.

For me this was at the same time frightening and magnificent. We certainly sympathised with our nearest neighbours from Austur-Eyjafjöll. The flooding that threatened a whole area was terrifying and moved us deeply... But this was fantastic and magnificent... I would not have liked to miss this experience (S).

\section{Receipt of cues and warnings.}

I got a phone call from the officers who were on duty. They called me and said a farmer reported a fire in the glacier, I didn't quite believe it... Veðurstofa [the Icelandic Meteorological Office] didn't see anything. The computer showed it was all very quiet $(\mathrm{O})$.

Environmental cues, observed and communicated by farmers in Fljótshlí as "a fire on top of the mountain", were the first notification that alerted officials and monitoring scientists that an eruption had commenced on 20 March 2010. It is therefore not surprising that half the respondents reported hearing about the eruption via a family member, friend or neighbour. A further $23 \%$ heard about the eruption from DCPEM/police while 14\% heard about it on the radio. None of the respondents had first noticed environmental cues as these were most visible from parts of Fljótshlíð, which was not included in the study region.

Once these observations were confirmed by police, and because the specific location of the eruption could not be verified- an evacuation for jökulhlaup hazard is only necessary if the eruption 


\begin{tabular}{|c|c|c|c|c|c|}
\hline & None & A little & Moderate & A great deal & Extreme \\
\hline You and your family's health & 41.2 & 23.5 & 15.7 & 13.7 & 5.9 \\
\hline You and your family financially & 34.0 & 18.0 & 16.0 & 18.0 & 14.0 \\
\hline You and your family emotionally & 26.4 & 17.0 & 26.4 & 20.8 & 9.4 \\
\hline
\end{tabular}

occurs under a glacier-officials initiated the pre-defined evacuation plans in the early hours of 21 March 2010. Evacuation orders were disseminated via the automated phone alert system, supervised by the local Chief of Police. Local police also personally contacted people in the area if they believed the evacuation orders were not received.

The first evacuation orders that residents in Vestur-Eyjafjöll and Austur-Eyjafjöll received came from DCPEM/police (38\% AE; $43 \%$ V-E), family, friends or neighbours (31\% A-E; $14 \%$ V-E) and, the rescue teams $(6 \% \mathrm{~A}-\mathrm{E} ; 14 \% \mathrm{~V}-\mathrm{E})^{1}$. Residents in Sólheimar and Álftaver stated they were not required to evacuate. The approximate 700 residents that evacuated were allowed to return to their homes when the eruption was confirmed in the flank of the volcano and not under the glacier.

Respondents' comments to corresponding open questions and during the interviews highlighted the importance of secondary sources of information as a means for residents to confirm the first source of news to evacuate. The points raised in the following excerpt taken from one interview with a resident were echoed by several other respondents.

The first alarm about the eruption in Fimmvörðuháls did not come to our phones. Something went wrong then...but our kids in Reykjavík, college students, they got an alarm. And it was on a Saturday night and we had a phone call from our youngest son... he called and said 'hey, there's an eruption. I had a text message from the Civil Defence authorities' and I said OK. And then our daughter called. She was a little more anxious. And she said 'You're supposed to evacuate!' But we didn't evacuate because we got no further information.

We of course ran to the TV and turned it on and turned on the computers and [motions typing on keyboard] and made phone calls and we had phones calls and then we tried to get more information from the television mostly and the internet and when we didn't get any more information we just went to bed. I think that's what most everyone did. [Initially] it had not been established as on Fimmvörðuháls but [we knew it was on the] east [side]. And we could see. We drove down to the highway and we could see a little reddish glow and of course we were excited, almost having fun because we were not afraid at all. Because there is no history of disaster in all the three eruptions in Eyjafjallajökull. It's more like Hekla erupting. It can be annoying. Scientists had already said many times that Eyjafjallajökull was a lazy crater with rather slow, small eruptions, not much coming out of the crater. So they were surprised when it turned out to be like a medium Katla. We believed the scientists when they said Eyjafjallajökull was lazy. So when it started we were more like 'What? Yeah!' [stated in a very blasé tone] (A-E).

Due to the flank eruption, residents' awareness was heightened when the summit eruption began in the early hours of 14 April
2010, with many reporting they were closely monitoring earthquake activity on the Icelandic Meteorological Office's website. Nevertheless, only 5\% reported environmental cues as the first notification they received that a second eruption had begun. $27 \%$ of respondents reported receiving news of the summit eruption from DCPEM/police. A further 21\% received news from family, friends or neighbours and $36 \%$ heard about it on the radio.

Again, evacuation orders were disseminated via the automated phone alert system with approximately 800 residents complying before daybreak on 14 April 2010. The first evacuation orders that residents in Vestur- and Austur-Eyjafjöll received this second time came from DCPEM/police (50\% A-E; 58\% V-E), family, friends or neighbours (28\% A-E; $8 \% \mathrm{~V}-\mathrm{E})$ and, the rescue teams $(6 \% \mathrm{~A}-\mathrm{E}$; $8 \% \mathrm{~V}-\mathrm{E})$. Again, residents in Sólheimar and Álftaver were not required to evacuate. This evacuation was warranted as the summit eruption, located under the glacier, produced mediumsized jökulhlaups to the north and small jökulhlaups to the south.

\section{Public response.}

I found it safer to be at a place where many of my countrymen were also (A-E).

A little over half the respondents indicated they evacuated during the flank (56\% A-E; 56\% V-E) and summit (54\% A-E; 47\% $\mathrm{V}-\mathrm{E}$ ) eruptions. These figures, however, should be treated with caution. One of the semi-structured interviews revealed that while the respondent marked on the questionnaire that they had evacuated, in reality, they had not. This person believed that the evacuation was necessary and that people should evacuate. However, they chose to stay at home because they were caring for elderly parents who were unwell. They marked the questionnaire as a positive response because they had intended to evacuate, as they believed it was the right thing to do, to the extent that they were concerned the police would come for them:

To be very honest, during the night and until the morning I was more scared of the police than the eruption! About them coming with the sirens [makes siren sounds] and taking me... I don't mind the eruption but please don't send the police! (A-E)

In addition to 'duty of care', non-compliance can be attributed to a belief that the warnings were irrelevant to the household.

The farm is on a hill and in my opinion there was no risk of flooding (A-E).

We never went, we behaved as we always planned to do, we just stayed at home and everything was ok (V-E).

Officials had, however, explained the need for a broad evacuation order even for areas that are safe from jökulhlaup hazards.

I said [at the pre-eruption meetings] that you have some safe areas but they are also isolated. It is much easier for me 
to have the people in the same area...because if someone gets heart attack, if someone gets hurt, it's very difficult to help them... Maybe you have to stay in your isolated farm for many days $(\mathrm{O})$.

However, some people viewed their homes as the safest option.

There is not any better place to be at [referring to the safety of his home]; there is no reason to be running somewhere (V-E).

Additionally, people were concerned about the designated evacuation centres. For example, many noted that Heimaland was a poor choice as they believe it is vulnerable to jökulhlaup emanating from Eyjafjallajökull because it is so low in the landscape and it is built in the old river bed of Markarfljót (V-E).

I found the place that people from Eyjafjöll were supposed to evacuate to not safe [Heimaland]. I therefore did not evacuate, as I felt safer at home (V-E).

What I found in the wrong was that I was made to evacuate my farm which is located such that it is not subjected to floods, and I was sent off across the risk area to Vík in Mýrdalur, and needed to cross many glacial rivers, and depending on the development of the volcanic activity, outburst floods could potentially have occurred in all of them. This evacuation could be listed as disorganised (A-E).

There was hardly any registration of who were where and who were missing (A-E).

Despite these issues, the majority of respondents believed both evacuations were necessary. However, more respondents acknowledged the necessity of evacuating during the summit eruption (75\%) than the flank eruption (54\%).

They could hardly do it differently. If it caused a flood in the rivers then we would of had only $1 \mathrm{~h}$ to escape. They didn't know where it was erupting and therefore it was necessary (A-E).

Evacuation went better because of the experience from previous eruption (V-E).

Officials were also very pleased with public response to the evacuation orders.

It is a small community. I was born here. I know most of the people that live here. It brought us much closer and then I knew also the trust that the people have in us. It was very good $(\mathrm{O})$.

Most of the things went very well because the people were really well prepared. Both Almannavarnir [DCPEM] and Björgunarsveitir [rescue teams], the Red Cross and the municipalities in the area were well organised. There are of course some things that we can do better and I think that most of that is regarding information to people. People feeling that they didn't get enough information. They were moved to a certain place but they didn't get the necessary information about why and how $(\mathrm{O})$.

Residents attributed this success to the desire to conform to authorities that are known to them on a more personal basis. Other factors noted by respondents were past experiences relating to the full-scale evacuation exercise practiced in 2006 for a Katla eruption (see Bird et al., 2009b) and the ongoing meetings right up until the flank eruption began.

Even if we already know that we are safe here...we are higher up so we are actually in no danger from the flood. But still I say the evacuation was necessary because I think what makes everything so easy and organised and good is people obey the authorities. You're told to evacuate and you do that. We had rehearsals years before and meetings and talks and it was in the back of our minds that everyone needed to evacuate if told to do so (A-E).

\section{Perceived levels of coping.}

That is of course how and why Iceland is settled, in general, after all, you just deal with the avalanches, you just deal with the everything, the cold winters, eruptions, because the good sides are so many, so you have to compromise (A-E).

Overall, residents believed they coped rather well with the eruptions (Table 3). Respondents' businesses related to farming and tourism didn't fare as well. Respondents reflected that they simply dealt with the situation at-hand knowing that it wouldn't last forever. They banded together with neighbours and friends to help each other through the tough times but they also had great concerns for their livestock.

We got away relatively well from ash fall and the jökulhlaup went only over grazing land and not cultivated land. We were though temporarily isolated because the road connection broke. The family took the situation as it was, slightly worried about the continuation; not knowing what to expect was the worst. But foremost you felt powerlessness, tranquillity, and respect towards nature (V-E).

I was concerned about the horses... I found it terrifying and I feared that the ash would [continue to increase in quantity] (Á).

Flexibility in the evacuation plans also helped people cope and residents were impressed with open and transparent communication from officials.

As soon as we knew when the flood had come we told the people that we would let them go home and feed their animals. They registered in and out of the area. They told us they needed $2 \mathrm{~h}$ and after $2 \mathrm{~h}$ if they hadn't come back we would call them $(\mathrm{O})$.

I started to explain to them what happened, why we evacuated in such a hurry...I waited to see the response and

Table 3 Respondents' perceptions of how well they thought they, their family $(n=55)$ and their farming $(n=45)$ and tourism businesses $(n=12)$ coped with the eruption

\begin{tabular}{|c|c|c|c|c|c|}
\hline & Not at all & A little & Moderately & A great deal & Completely \\
\hline You and your family & 3.6 & 10.9 & 34.5 & 36.4 & 14.5 \\
\hline Farming business & 2.2 & 28.9 & 33.3 & 28.9 & 6.7 \\
\hline Tourism business & 25.0 & 33.3 & 25.0 & 8.3 & 8.3 \\
\hline
\end{tabular}



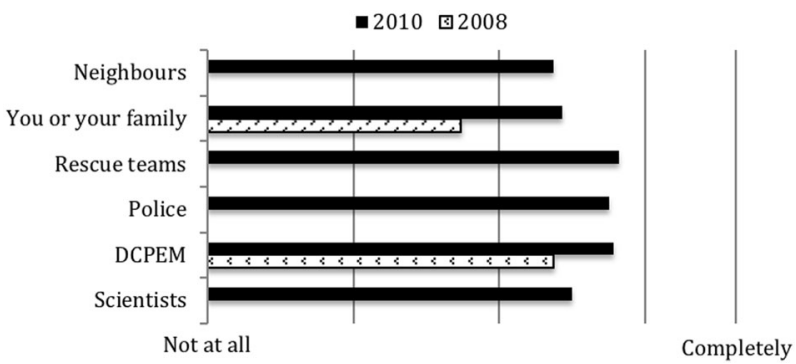

Fig. 3 Average sentiment (where $1=$ not at all and $5=$ completely) in regards to respondents' perception of the levels of preparedness for a Katla eruption $(\mathrm{n} 2008=19, \mathrm{n} 2010=54-56)$

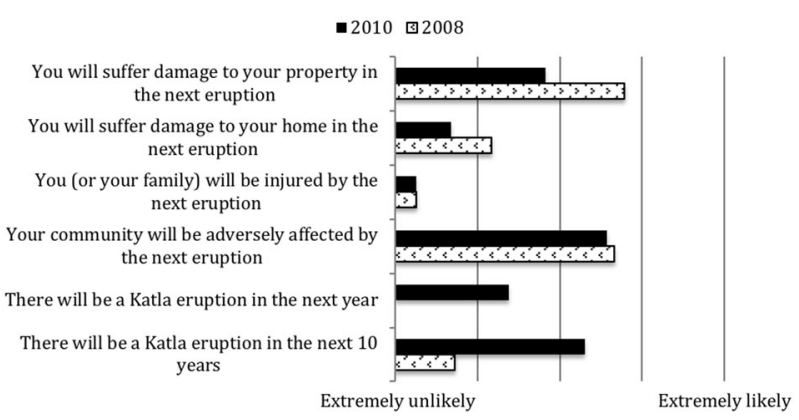

Fig. 4 Average sentiment (where $1=$ extremely unlikely and $5=$ extremely likely) in regards to respondents' perception of the possibility of a Katla eruption and its effects $(\mathrm{n} 2008=19, \mathrm{n} 2010=50-54)$

get the anger but it was quite the opposite. They said we feel safe at home because we know you are watching us $(\mathrm{O})$.

Perceptions of the future. With respect to the future, respondents were asked about how they viewed preparedness for a Katla eruption. Included in this section is 2008 data derived from Bird et al., (2011) from the communities of Sólheimar and Álftaver. While we are not able to show statistically significant differences between the datasets due to the small size and slightly different nature of the 2008 dataset (e.g., it does not include respondents from Vestur-Eyjafjöll and Austur-Eyjafjöll), we can present some interesting observations. Namely, it appears that residents believe they, their families and the DCPEM are better prepared for a Katla eruption based on the Eyjafjallajökull experience (Fig. 3) an observation that is supported by verbatim quotes presented in the previous sections.

While 2010 respondents believed it is more likely a Katla eruption will occur in the next 10 years, they perceived less damage would occur particularly in relation to their property (Fig. 4). This optimism was frequently linked to their experience of Eyjafjallajökull.

People talked about the possibility of Eyjafjallajökull [erupting], and we were light-hearted about it you know, saying wow, it can erupt. But it didn't worry us at all. We would be much, much more afraid if somebody told us about the possibility of a huge earthquake in the ocean with the coast with a wave [tsunami]. That would scare us much more. Also if they told us there was a huge, huge snowstorm coming like in the West Fjords and we could

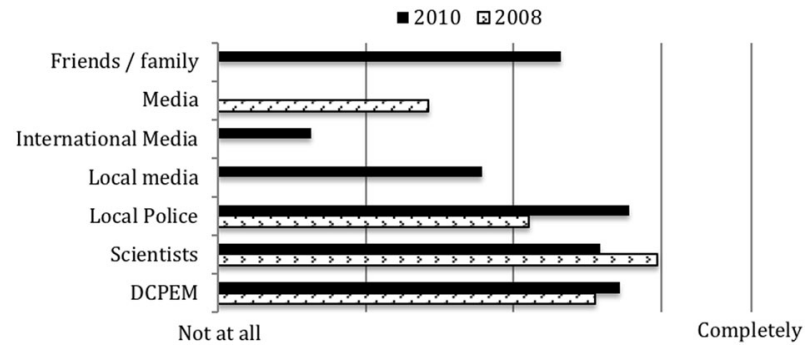

Fig. 5 Average sentiment (where $1=$ not at all and $5=$ completely) in regards to respondents' levels of trust in information from various sources about a future Katla eruption (n2008 =19, n2010 =54-58)

have an avalanche. That would worry us. But an eruption does not worry us. I would be anxious. But I would not be afraid. I don't think that anyone around here was afraid. And I have the same feeling about Katla (A-E).

The open and transparent communication from police, and ensuing trust that developed between them and residents, as described in the previous sections, supports the data observed in Fig. 5 which shows residents have much more trust in information from local police in 2010 than respondents did in 2008 .

2016 interviews. The officials interviewed in 2016 were extremely positive about their relationship with local residents and the trust that residents have in them and the volcanic response plans. Because of this, officials have faith that residents will comply with evacuation orders when given, as they did during the 2010 Eyjafjallajökull eruptions. However, they have grave concerns for the safety of the ever-increasing number of tourists visiting the South region.

It's all going very well in a way but it's a huge change because the tourists have multiplied - there are a lot more tourists here than there used to be three years ago. We are not worried about the people living here because they know what do to, but the tourists, there's a lot of them and we're afraid $(\mathrm{O})$.

It was noted that the region attracts all types of travellers, from large tour groups, to individuals in rental cars, people on private tours, campervans and hitchhikers. And more times than not, their interest is volcanoes as they remember the 2010 eruption in the summit of Eyjafjallajökull.

They don't seem like they are afraid or trying to get information about when the next [eruption] comes. They are just visiting the country; they think it's a plus if they can find some volcanoes and maybe have their picture of it. And of course [Eyjafjallajökull] they want to say they've been here. I don't think they realise the risk of an eruption (A-E).

Concern was also raised with respect to the lack of knowledge and interest among young Icelanders, with one of the residents stating that more emphasis should be placed on teaching the geography and geology of Iceland to primary school through to college students.

I don't think they [Icelandic children] think enough about their own country. I would like to see more emphasis on this, like volcanic activity, geothermal, everything 


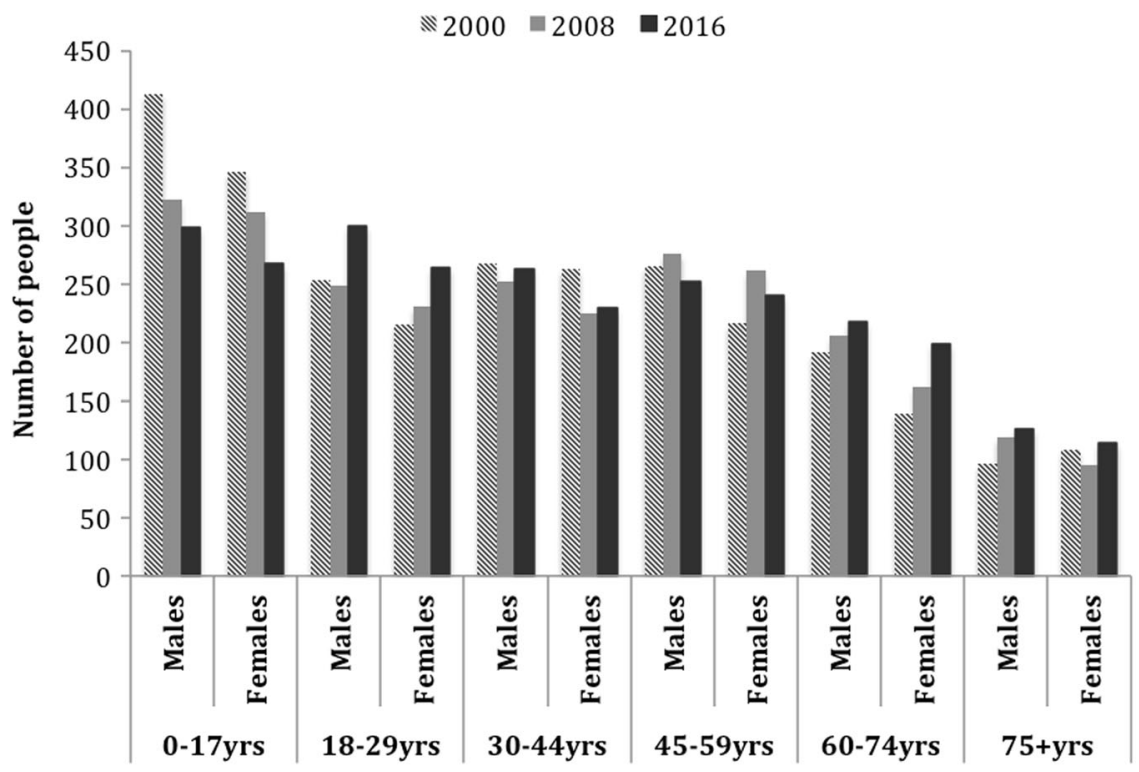

Fig. 6 Population of Mýrdalshreppur, Skaftárhreppur and Rangárping eystra by age and sex. Data derived from Statistics Iceland (2017a)

geography in Iceland because we're having the tourists now... [But] we have our children who are not finding out about those things. They are the future who should be taking over (A-E).

This sentiment was not only directed to children growing up in the suburbs of Reykjavík, but also to the local farming region.

Our primary school here in the area, they don't do anything special about this area. They could put more effort in it. The kids they can learn everything. They are so enthusiastic. And I think they should try to take that enthusiasm and bring it forward. You have to know what is around you. Iceland is not big so it should be possible to teach (A-E).

The lack of resources was also noted as an impeding factor in the South region. While interviewees stated that available resources were insufficient in dealing with the increased number of tourists visiting the area they also raised concerns relating to the amalgamation of districts on 1 January 2015. This amalgamation resulted in just one jurisdiction for South Iceland that incorporates 14 municipalities (Stjórnarráð Íslands 2014a, 2014b) and three local Civil Protection Committees that the South Iceland Chief of Police oversees (see Fig. 2).

This summer [2016] we have more accidents and more calls for the rescue teams to Fimmvörðuháls than before. The calls are increasing. People used to be everywhere and it's still the same, but now there are 30 times, 100 times more [tourists]. This district is now about $31,000 \mathrm{~km}^{2}$. We have a similar amount of policemen as we had in 2004 (O).

In relation to the amalgamation and the timing of the 2006 evacuation exercise, one of the rescue team members from the 2010 interviews stated:

The time for the evacuation exercises in 2006 was not logical because it had been decided that the police districts would be joined here in the south. It would have therefore been more logical to practice it under the new police jurisdiction once it had been created (RT).

In addition to the everyday work of the local rescue teams, these officials will again call upon the sweeper system to help disseminate warning messages and check that individual households have complied with evacuation orders.

We still have the sweeper system... it is difficult to depend only on the mobile phones so we still have the sweeper system $(\mathrm{O})$.

The changing demographics of South Iceland. Population numbers in Mýrdalshreppur, Skaftárhreppur and Rangárping eystra-the municipalities impacted by the Eyjafjallajökull eruption-have been fairly consistent, with a total number of 2772 , 2710 and 2769 recorded in 2000, 2008 and 2016, respectively. The structure of the population, however, changed during this period with losses in the $0-17$ year and $30-44$ year age categories across both genders between 2000 and 2016 (Fig. 6). This loss was most keenly felt in the male age group 0-17 years (loss of 0.72 ). Balancing this loss was growth in all other categories (except 45-59 year old males) between 2000 and 2016, with the greatest among females 60-74 years (growth of 1.43), males 75+ years (growth of 1.31 ) and females (growth of 1.23) and males 18-29 years (growth of 1.19).

Another noteworthy change in the population structure of the South region is the increase in migration. Following the collapse of Iceland's banking system in October 2008 (Danielsson, 2009), the region has experienced an increase in international migration (growth of 2.54 between 2009 and 2016), as well as that from the capital region (growth of 1.30 between 2011 and 2016), as shown in Fig. 7.

Before the financial crash in 2008, Iceland had become too expensive for many visitors-evidenced by a somewhat steady decline in employment numbers within the tourism industry outside the capital region from 2000 (Fig. 8). Since then, the industry has flourished resulting in a rapid increase in employment numbers particularly since 2012-corroborating the statements from officials in 2016. As a result, 2016 recorded the highest number of people employed in tourism. At the same time, the number of people involved in farming activities outside the capital region declined, with 2016 portraying the lowest employment rates in the industry since 1991. 


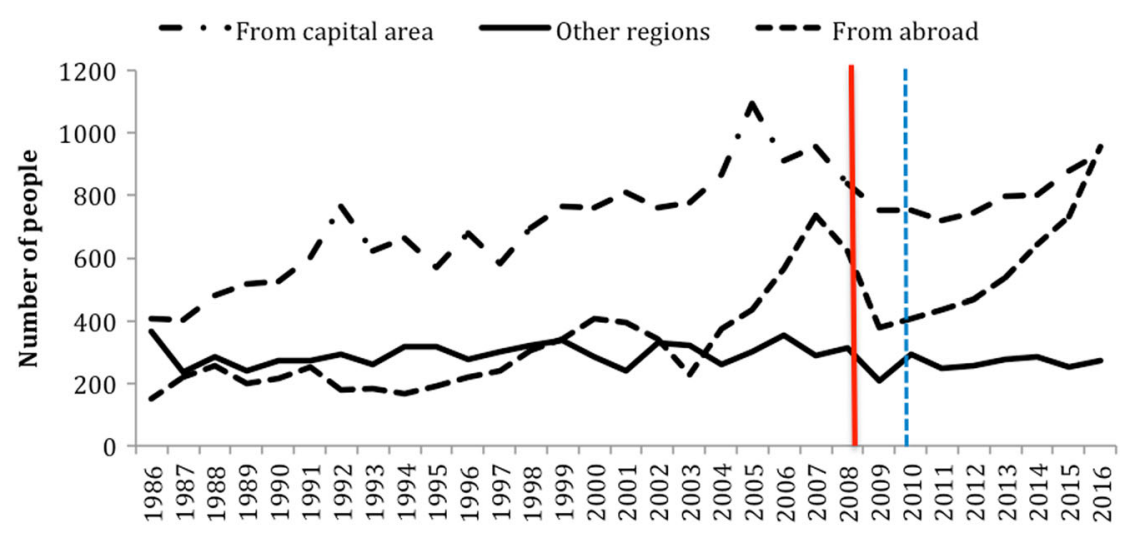

Year

Fig. 7 Migration into the South region (Statistics Iceland, 2017b). Solid red vertical line indicates timing of Iceland's financial crash in 2008. Dashed blue vertical line indicates the occurrence of the Eyjafjallajökull eruptions in 2010

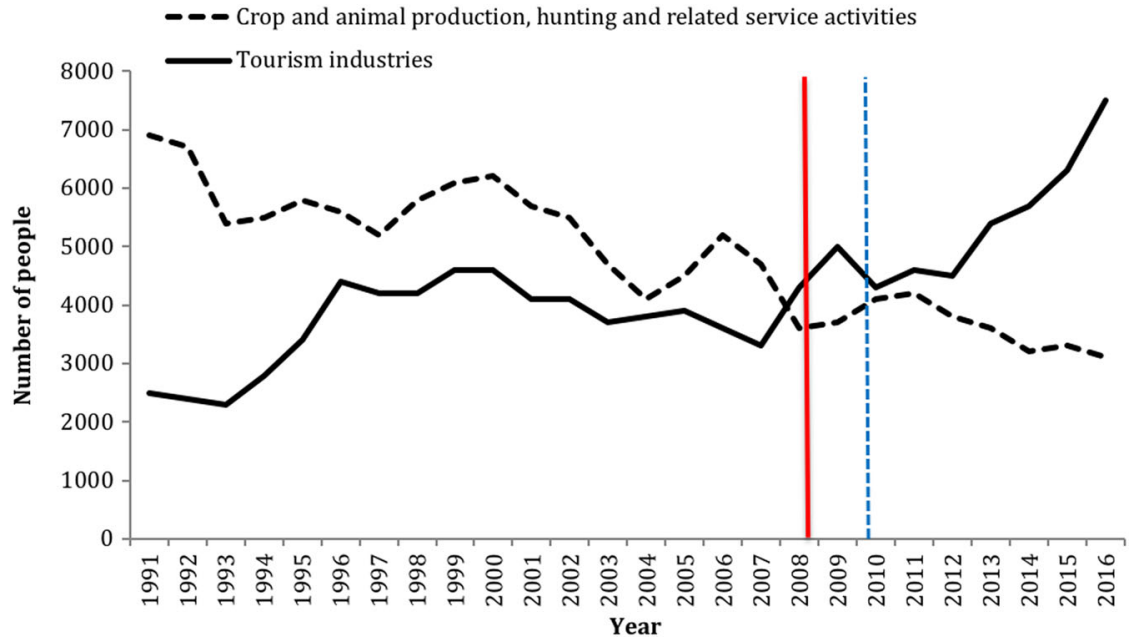

Fig. 8 Total number of people employed in main and second jobs held outside the capital region and within the farming (crop and animal production, hunting and related service activities) and tourism sectors (Statistics Iceland, 2017c)

\section{Discussion}

The relatively small, homogenous population of Iceland, with a tradition of integrated research, policy and practice and, as well as its peoples' strong desire to cooperate have been attributed as factors influencing the success of community-based health interventions (Sigfúsdóttir et al., 2009). The data presented here clearly shows that the success of the 2010 evacuations, which were a risk mitigation intervention, is no different-from the integrated approach employed during the 2005 hazard assessment (Guðmundsson and Gylfason, 2005), the 2006 evacuation exercise (Bird et al., 2009b), the 2010 meetings and throughout the 2010 response (Bird et al., 2018), to the South region's communities where neighbours interact relatively frequently due to their beliefs, values and activities. Even where compliance did not occur, residents showed respect for authority and the jobs they were undertaking, despite the errors and confusion.

Within these local communities (geographic location), people are bound together by relations of affect, loyalty and common values and as such, they have a certain familiarity with each other (Brint, 2001). Not only is this evident in the study region between neighbours, but also between residents, scientists, officials and local police. It does not mean, however, that all relationships are amicable. Nevertheless, as Brint (2001; p. 9) highlights, "a sense of security in the face of disliked others is deeply characteristic of communal relations". That is, these communities look to each other for guidance and support during times of crisis.
However, the changing economic, demographic and political landscape will test this phenomenon. As our results indicate, political changes have resulted in a lack of available resources for police, civil defence and emergency management. There is also economic change occurring with respect to people's livelihoods. Demographic changes most notably include greater international migration and migration from the capital region. The population is also aging but at the same time, the number of children and youths in the region has decreased while the number of young adults has increased.

The inherent challenges this enhanced diversity brings with respect to developing risk mitigation strategies cannot be ignored. In a simple comparison of populations (urban and rural residents of South Iceland), Bird et al., (2011) identified different perceptions and beliefs, and therefore different needs with respect to risk mitigation. For example, rural residents responsible for livestock questioned their ability to comply with evacuation orders (Bird et al., 2009b, Bird et al., 2011). The police overcame this issue during the 2010 evacuations by allowing farmers to re-enter the hazard zones to tend their livestock. That is, local police/DCPEM worked with local residents to ensure safety from an imminent threat, as well as protecting livelihood interests. Furthermore, residents were not kept at the evacuation centre any longer than needed. This positive experience enabled compliance with subsequent evacuation notices when the second stage of the eruption began at the summit of Eyjafjallajökull. 
Despite this, the results presented here show not all residents evacuated in 2010 ( $47 \%$ of our respondents). Even though some considered it the right thing to do, they decided to shelter in place (e.g., within their own home) because they had a duty of care to family members and believed this was the safest option. Others chose to stay home because they did not believe the warnings and/or evacuation plan were relevant to them. Exact figures on how many people were supposed to evacuate during both phases of the eruption are not available. It is almost impossible to know exactly how many people are located in a given area at any point in time. Exact figures on how many people evacuated during both phases are also not available. This lack of detail can be attributed to people sheltering in unofficial places (either by choice or official instruction to do so) and as reported by a few respondents, registration was not well organised in some instances.

Nevertheless, officials were pleased with public response. As evidenced by the results presented here and by Bird et al., (2018), compliance with evacuation orders can be attributed to: trust in the information source; recency of community meetings regarding a potential eruption (i.e., people were able to easily retrieve relevant information from memory); and, a strong desire to abide by social norms (normative beliefs). Not only was this apparent in regards to residents wanting to abide by police orders, but also with respect to their neighbours and the local rescue team.

Furthermore, the required action, i.e., to evacuate, was clearly communicated. The first and foremost hazard risk that authorities focus on is jökulhlaup, as emphasised in historical accounts, the 2006 evacuation exercise, and most recent meetings. Residents are aware that until the site of the eruption is confirmed, and hence the path of a potential jökulhlaup, all low-lying regions close to flood channels are considered to be hazard zones. Hence, it is well known that if you are located in these areas you must evacuate-highlighting geographic location as an important factor influencing decision-making. It is therefore not surprising that people contested the location of some evacuation centres, particularly those located in low-lying regions and old flood channels. And despite the clarity of the prescribed action to evacuate, some residents received conflicting information regarding the location of their designated centre.

To be effective, warnings need to be clear, precise and consistent as people will focus on minor points of inconsistency to support their decision to reject proposed actions (Drabek, 1999). Given the complexities of risks associated with volcanic hazards in Iceland-e.g., jökulhlaups, lightning, poisonous gases, as well as ash fall-it is critical that these are clearly communicated with sufficient detail to avoid confusion among new residents. This is particularly pertinent among those that have immigrated from abroad. As Bird et al., (2010) found, foreigners are often not aware of the fact that volcanoes lie underneath some of Iceland's glaciers and as such, are not aware of jökulhlaup risk nor are they aware of the risk of lightning and poisonous gases. However, rather than just focusing information on the risk itself it is essential to communicate actionable risk, i.e., what actions people need to take with respect to reducing their personal risk (Drabek, 1999, Mileti et al., 2004, Wood et al., 2012).

Communication and risk mitigation strategies must also be tailored to meet the changing population's needs. A one-size-fitsall approach among diverse populations is unlikely to generate a proactive public response to future evacuation orders (Mileti et al., 2004, Paveglio et al., 2017, Tierney et al., 2001). For example, there are distinct differences between decision-making and actions undertaken by men and women (Haynes et al., 2016, Haynes et al., 2010) and age plays a significant role, with younger males often taking greater risks than older age groups and women across all age groups (Haynes et al., 2016).

With the rapidly increasing number of tourists in the region, the police/DCPEM may need to consider further non-compliance, particularly among tour operators and tourist accommodation managers/staff due to their duty of care to their patrons. This may be particularly apparent if their patrons are out sightseeing and are therefore unaccountable, which is just as likely during the night (e.g., on a Northern Lights tour) as it is during the day. With more people engaging in tourism, the police/DCPEM should also be cognisant of the possibility of tour operators feeling obliged to engage in activities that enhance their vulnerability. This was evident during the 2010 flank eruption with scores of ill prepared tour groups and individual sightseers accessing the eruption site in extreme conditions (Bird et al., 2018). There is no doubt that many tourists want to see an eruption, as was the case with Hawaii's Kilauea eruption in 2018 (Walker, 2018), and may try to persuade their guides to deliver.

As discussed elsewhere (e.g., Mileti and Sorensen, 1990), friends, family and neighbours were invaluable in communicating official warnings. These kin, friend and community networks not only provide an added element of warning dissemination, but also provide an additional source with whom warning-recipients can verify the legitimacy of information (Lindell and Perry, 2004). It is important to note that these networks have become more accessible and much greater with the advent of social media and the reliance on it for risk and crisis communication (Bird et al., 2012, Sennert et al., 2015), notwithstanding the challenges that brings. Furthermore, the region's mobile communication network is much improved to that used during the Eyjafjallajökull eruption. Authorities now have the ability to push emergency notifications out to all mobile phones within a designated area of telecommunication towers (pers. comm. Sveinn Rúnarsson, 2018).

Despite these advances, Iceland's 'sweeper system' is still considered a critical component of the communication network. In some instances, the sweepers provide the only link between emergency management officials and the community (Bird et al., 2009 b), further bolstering the work of the rescue teams at the local level. Ensuring the sustainability of local rescue teams and the sweeper system is critical, as their roles during future events may become even more important with respect to reaching new residents and tourists that are not connected to kin, friend and community networks.

New residents may also benefit from storytelling, involving detailed accounts from people who experienced the event. People who lack their own personal experience (i.e., new residents, tourists) might be influenced by vivid accounts from other members of the public more so than from volcanologists communicating geophysical probabilistic data (Lindell and Perry, 2004). However, experience of an event, either direct or vicarious, can lead people to expect similar impacts from future events. That is, they may be unable to perceive worse impacts from a different scenario than that they've already experienced (Tversky and Kahneman, 1973). Hence, memories of a significant experience, e.g., that relating to the Eyjafjallajökull eruption, may influence people's response to a future event, e.g., a catastrophic Katla eruption.

In this instance, emergency managers need to be aware of normalisation bias, where individuals believe they are able to cope with a future (larger) event, based on a past experience of coping with a previous (smaller) event (Paton et al., 2001). Our results here showing an increase in perceived preparedness and decrease in perception of risk associated with damage to property and home may stem from the relatively low impacts of the Eyjafjallajökull eruptions and the fact that residents believed they coped moderately well, in general.

At the same time, however, respondents still viewed a similar level of risk to the community as a whole in terms of adverse impacts. This unrealistic optimistic bias, where people consider themselves less vulnerable than others in their community (Paton et al. 2008, Sjöberg, 2000, Weinstein, 1987), may be directly linked to residents' predicting their future vulnerability based on their personal experience of the Eyjafjallajökull eruptions. It may also relate to the incessant news broadcasts that some believed exaggerated the level of impacts in the region (Bird et al., 2011, 
Bird et al., 2018). That is, based on media reports, residents deem others suffered far greater impacts than themselves and therefore consider them more vulnerable. Because of this, optimistic residents may be less inclined to respond to a future event.

Importantly, there is greater trust in those responsible for public safety, i.e., local police and the DCPEM. It is apparent that this trust has stemmed from open, regular and transparent communication well before and throughout the Eyjafjallajökull eruptions. Residents' trust in these officials has also evolved from officials listening to and developing strategies to meet the needs of the community. To ensure this trust is maintained, officials must continually engage and work with the population of South Iceland as the region's demographic, economic and political landscape changes.

It is important to note, however, that the perspectives presented here are predominantly drawn from a survey implemented during the early to medium-term stages of recovery (where early and medium are classified as 'beginning to resume some kind of normal existence' and 'life is finally beginning to feel stable' (Crutchfield, 2013), respectively). That is, our study does not incorporate perspectives on long-term impacts and how they may influence people's decision-making during a future event due to ongoing physical and mental health impacts. While this is a limitation of the present study, we do not believe it detracts from the overall results. By undertaking research within this time period, we were able to capture more detailed and accurate narratives of actions and perspectives of the decision-making process, given that intricate details of which fade with time. Given the immediate need for evacuation, particularly for a catastrophic Katla eruption, these perspectives provide a critical viewpoint of how and why people behave the way they do when faced with a volcanic crisis. Coupled with the changing social characteristics, this paper provides a unique perspective of how residents may behave when faced with future evacuation orders.

From a societal viewpoint, the results highlight the need for local authorities to continually engage the local population in risk mitigation strategies and procedures. In doing so, they will gain an enhanced understanding of the changing population and be in a position to adjust strategies to suit the population's needs. The research also highlights the importance of local residents knowing and sharing their stories and experiences with their neighbours. And, it stresses the importance of residents considering the changes in their livelihoods and what that may mean with respect to their vulnerability during a volcanic crisis. As the communities diversify, so too will people's beliefs, values and activities. This greater complexity will inevitably create greater challenges for the local police and DCPEM. However, while it may enhance some aspects of vulnerability, it may also bring about new opportunities for developing new and exciting methods for generating a proactive public response to future evacuation orders among new and old residents.

Significantly, this paper links together longitudinal research that spans more than a decade capturing an at-risk population's perspectives of: inherited knowledge, hazard assessments, risk mitigation strategies including a full-scale evacuation exercise; to their response during and perspectives of a volcanic crisis. It is rare to find such a detailed study that spans the before and aftera perspective that is often unattainable due to the nature of natural hazard events.

\section{Data availability}

The datasets generated during and/or analysed during the current study are not publicly available due to human research ethics agreements but may be made available from the corresponding author on reasonable request. Data collection tools are available from the lead author on request. Survey data are not available for distribution as per anonymity protocols of the Human Research Ethics agreement.
Received: 9 July 2018 Accepted: 15 November 2018

Published online: 20 December 2018

\section{Notes}

1 Please note, the questionnaire did not specifically ask respondents whether or not they received information from a sweeper. This is because the sweepers, who are residents of the immediate neighbourhood, are only active during a volcanic eruption. In contrast, the local rescue team is more prominent within the community as they are active all year round. Hence, respondents know the person as a neighbour or as a rescue team member rather than a sweeper.

\section{References}

Almannavarnadeild Ríkislögreglustjórinn (2017) Emergency Evacuation-Öræfajökull. 23.11.2017-Version 1.0. http://www.almannavarnir.is/utgefid-efni/? wpdmc $=$ articles-in-english. Accessed 9 April 2018

Bird D, Gísladóttir G (2012) Residents' attitudes and behaviour before and after the 2010 Eyjafjallajökull eruptions-a case study from southern Iceland. Bull Volcanol 74:1263-1279

Bird D, Gísladóttir G (2014) How the children coped with the April 2010 Eyjafjallajökull eruption in Iceland. Aust J Emerg Manag 29:50-55

Bird D, Ling M, Haynes K (2012) Flooding Facebook-the use of social media during the Queensland and Victorian floods. Aust J Emerg Manag 27:27-33

Bird D, Mcleman R, Gísladóttir G, Kelman I, Næss MW, Pétursdóttir G, Jóhannesdóttir G (2016) Climate change and settlement level impacts. In: Taylor A, Carson D, Ensign P, Huskey L, Rasmussen R (eds) Settlements at the edge: remote human settlements in developed nations. Edward Elgar, UK

Bird DK, Gisladottir G, Dominey-Howes D (2010) Volcanic risk and tourism in southern Iceland: Implications for hazard, risk and emergency response education and training. J Volcanol Geotherm Res 189:33-48

Bird DK, Gísladóttir G, Dominey-Howes D (2009a) Public perception of jökulhlaup hazard and risk in Iceland: implications for community education. Int J Manag Decis Mak 10:164-175

Bird DK, Gísladóttir G, Dominey-Howes D (2009b) Resident perception of volcanic hazards and evacuation procedures. Nat Hazards Earth Syst Sci 9:251-266

Bird DK, Gísladóttir G, Dominey-Howes D (2011) Different communities, different perspectives: Issues affecting residents' response to a volcanic eruption in southern Iceland. Bull Volcanol 73:1209-1227

Bird DK, Jóhannesdóttir G, Reynisson V, Karlsdóttir S, Gudmundsson MT, Gísladóttir G (2018) Crisis Coordination and Communication During the 2010 Eyjafjallajökull Eruption. In: Fearnley CJ, Bird DK, Haynes K, Mcguire WJ, Jolly G (eds) Observing the Volcano World: Volcano Crisis Communication. Springer International Publishing, Cham

Brint S (2001) Gemeinschaft revisited: a critique and reconstruction of the community concept. Sociol Theory 19:1-23

Crutchfield M (2013) Phases of disaster recovery: emergency response for the long term. https://reliefweb.int/report/world/phases-disaster-recovery-emergencyresponse-long-term. Accessed 15 Oct 2018

Danielsson J (2009) The first casualty of the crisis: Iceland. In: Felton A, Reinhart CM (eds) The First Global Financial Crisis of the 21st Century: Part ll JuneDecember 2008. Centre for Economic Policy Research, London

Dash N, Gladwin H (2007) Evacuation decision making and behavioral responses: individual and household. Nat Hazards Rev 8:69-77

Drabek TE (1986) Human system responses to disaster: an inventory of sociological findings. Spring-Verlag, New York

Drabek TE (1999) Understanding disaster warning responses. Soc Sci J 36:515-523

Gladwin C, Gladwin H, Peacock WG (2001) Modeling hurricane evacuation decisions with ethnographic methods. Int J Mass Emerg Disasters 19:117-143

Guðmundsson MT, Gylfason ÁG (2005) Hættumat vegna eldgosa og hlaupa frá vestanverðum Mýrdalsjökli og Eyjafjallajökli. Ríkislögreglustjórinn and Háskólaútgáfan, Reykjavík

Guðmundsson MT, Höganadóttir P, Kristinsson AB, Guðbjörnsson S (2007) Geothermal activity in the subglacial Katla caldera, Iceland, 1999-2005, studied with radar altimetry. Ann Glaciol 45:66-72

Gudmundsson MT, Thordarson T, Höskuldsson Á, Larsen G, Björnsson H, Prata FJ, Oddsson B, Magnússon E, Högnadóttir T, Petersen GN, Hayward CL, Stevenson JA, Jónsdóttir I (2012) Ash generation and distribution from the April-May 2010 eruption of Eyjafjallajökull, Iceland. Sci. Rep. 2:572

Haynes K, Barclay J, Pidgeon N (2008) The issue of trust and its influence on risk communication during a volcanic crisis. Bull Volcanol 70:605-621

Haynes K, Coates L, Oliveira FDD, Gissing A, Bird D, Honert RVD, Radford D, D'arcy R, Smith C (2016) An analysis of human fatalities from floods in Australia 1900-2015. Report for the Bushfire and Natural Hazards CRC, Melbourne 
Haynes K, Handmer J, Mcaneney J, Tibbits A, Coates L (2010) Australian bushfire fatalities 1900-2008: exploring trends in relation to the 'Prepare, stay and defend or leave early' policy. Environ Sci Policy 13:185-194

Höskuldsson Á (2015) Öræfajökull. In: Lyinskaya E, Larsen G, Gudmundsson MT (eds) Catalogue of Icelandic Volcanoes. IMO, UI, CPD-NCIP, Reykjavík

Jóhannesdóttir G, Gísladóttir G (2010) People living under threat of volcanic hazard in southern Iceland: vulnerability and risk perception. Nat Hazards Earth Syst Sci 10:407-420

Lindell MK, Perry RW (2004) Communicating environmental risk in multiethnic communities. Sage, Thousand Oaks

Lindell MK, Perry RW (2012) The protective action decision model: theoretical modifications and additional evidence. Risk Anal 32:616-632

Mileti D, Nathe S, Gori P, Greene M, Lemersal E (2004) Public hazards communication and education: the state of the art. Natural Hazards Informer, Boulder, Issue 2

Mileti DS, Peek L (2000) The social psychology of public response to warnings of a nuclear power plant accident. J Hazard Mater 75:181-194

Mileti DS, Sorensen JH (1990) Communication of emergency public warnings: a social science perspective and state-of-the-art assessment. Oak Ridge National Laboratory, U.S. Department of Energy, Oak Ridge

Paton D, Johnston DM, Bebbington MS, Lai C-D, Houghton BF (2001) Direct and vicarious experience of volcanic hazards: implications for risk perception and adjustment adoption. Aust J Emerg Manag 15:58-63

Paton D, Smith L, Daly M, Johnston D (2008) Risk perception and volcanic hazard mitigation: individual and social perspectives. J Volcanol Geoth Res 172:179-188

Paveglio TB, Boyd AD, Carroll MS (2017) Re-conceptualizing community in risk research. J Risk Res 20:931-951

Sennert SSK, Klemetti EW, Bird DK (2015) Role of social media and networking in volcanic crises and communication. In: Fearnley CJ, Bird DK, Haynes K, Mcguire WJ, Jolly G (eds) Observing the volcano world: volcano crisis communication. Springer International Publishing, Cham

Sigfúsdóttir ID, Thorlindsson T, Kristjánsson ÁL, Roe KM, Allegrante JP (2009) Substance use prevention for adolescents: the Icelandic Model. Health Promot Int 24:16-25

Sigurðsson O, Sigurðsson G, Björnsson BB, Pagneux EP, Zóphóníasson S, Einarsson B, Pórarinsson Ó, Jóhannesson T (2011) Flood warning system and jökulhlaups-Eyjafjallajökull [Online]. Icelandic Meteorlogical Office, Reykjavík

Sjöberg L (2000) Factors in risk perception. Risk Anal 20:1-12

Sorensen JH, Sorensen BV (2007) Community processes: warning and evacuation. In: Rodríguez H, Quarantelli EL, Dynes RR (eds) Handbook of disaster research. Springer, New York

Statistics Iceland (2016) Population by municipalities, sex and age 1 January 19982016-Current municipalities. http://px.hagstofa.is/pxen/pxweb/en/Ibuar/ Ibuar_mannfjoldi_2_byggdir_sveitarfelog/MAN02001.px/table/ tableViewLayout1/?rxid=e87bdd18-bb84-4e71-8c4f-611b8d583564. Accessed 8 Nov 2016

Statistics Iceland (2017a) Population by municipality, age and sex 1998-2017 Division into municipalites as of 1 January 2017. http://px.hagstofa.is/pxen/ pxweb/en/Ibuar/Ibuar_mannfjoldi_2_byggdir_sveitarfelog/MAN02005. px/table/tableViewLayout1/?rxid=813b90ba-b0e0-4863-a995-a9c8bb7e9bbc Accessed 1 Dec 2017

Statistics Iceland (2017b) Internal migration between regions by sex and age 19862016-Division into municipalites as of 1 January 2017. http://px.hagstofa.is/ pxen/pxweb/en/Ibuar/

Ibuar_buferlaflutningar_buferlaflinnanlands_buferlaflinnanlands/ MAN01002.px. Accessed 29 Nov 2017

Statistics Iceland (2017c) At work in main and second job by economic activity, sex and region 1991-2016. Available: http://px.hagstofa.is/pxen/pxweb/en/ Samfelag/Samfelag_vinnumarkadur_3_arstolur/VIN01111.px. Accessed 8 Dec 2017

Stiórnarrád Îslands (2014a) Innanríkisráðherra setur nýjar reglugerðir um 9 sýslumannsumdæmi og 9 lögregluumdæmi. https://www.stjornarradid.is/efst-abaugi/frettir/stok-frett/2014/12/19/Innanrikisradherra-setur-nyjarreglugerdir-um-9-syslumannsumdaemi-og-9-logregluumdaemi/. Accessed 14 Apr 2018
Stjórnarráð Íslands (2014b) Reglugerð. https://www.stjornarradid.is/media/ innanrikisraduneyti-media/media/frettir-2014/logreglan.pdf. Accessed 14 Apr 2018

Strahan K, Whittaker J, Handmer J (2018) Self-evacuation archetypes in Australian bushfire. Int J Disaster Risk Reduct 27:307-316

Thordarson T, Larsen G (2007) Volcanism in Iceland in historical time: volcano types, eruption styles and eruptive history. J Geodyn 43:118-152

Porkelsson B (2012) The 2010 Eyjafjallajökull eruption, Iceland. Report to ICAOJune 2012. Icelandic Meteorological Office; Institute of Earth Sciences, University of Iceland; The National Commissioner of the Icelandic Police, Reykjavik

Tierney KJ, Lindell MK, Perry RW (2001) Facing the unexpected: disaster preparedness and response in the United States. Joseph Henry Press, Washington, D.C

Tversky A, Kahneman D (1973) Availability: a heuristic for judging frequency and probability. Cogn Psychol 4:207-232

Walker P (2018) Kilauea volcano eruption. Tourists arrested for entering restricted zones to take photos, Hawaii. http://www.traveller.com.au/kilauea-volcanoeruption-hawaii-tourists-arrested-for-entering-restricted-zones-to-take-. Accessed 22 September 2018

Weinstein ND (1987) Unrealistic optimism about susceptibility to health problems: conclusions from a community-wide sample. J Behav Med 10:481-500

Wisner B, Blaikie P, Cannon T, Davis I (2004) At risk: natural hazards, people's vulnerability, and disasters. Routledge, New York

Wood MM, Mileti DS, Kano M, Kelley MM, Regan R, Bourque LB (2012) Communicating actionable risk for terrorism and other hazards $\star$. Risk Anal 32:601-615

\section{Acknowledgements}

All interviewees and respondents are graciously thanked for their willingness to participate in this study. Contributions from the Ash Fall Impacts Working Group, Katharine Haynes, Carolina Garcia Londoño and Guðrún Pétursdóttir are appreciated in relation to the development of the questionnaire. The 2016 interviews and the preparation of this paper were supported by the Nordic Centre of Excellence for Resilience and Societal Security-NORDRESS, which is funded by the Nordic Societal Security Programme.

\section{Additional information}

Competing interests: The authors declare no competing interests.

Ethical approval: This research was conducted in accordance with Human Research Ethics Regulations outlined by the University of Iceland and involved obtaining informed consent from all participants.

Reprints and permission information is available online at http://www.nature.com/ reprints

Publisher's note: Springer Nature remains neutral with regard to jurisdictional claims in published maps and institutional affiliations.

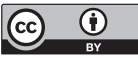

Open Access This article is licensed under a Creative Commons Attribution 4.0 International License, which permits use, sharing, adaptation, distribution and reproduction in any medium or format, as long as you give appropriate credit to the original author(s) and the source, provide a link to the Creative Commons license, and indicate if changes were made. The images or other third party material in this article are included in the article's Creative Commons license, unless indicated otherwise in a credit line to the material. If material is not included in the article's Creative Commons license and your intended use is not permitted by statutory regulation or exceeds the permitted use, you will need to obtain permission directly from the copyright holder. To view a copy of this license, visit http://creativecommons.org/ licenses/by/4.0/

(c) The Author(s) 2018 